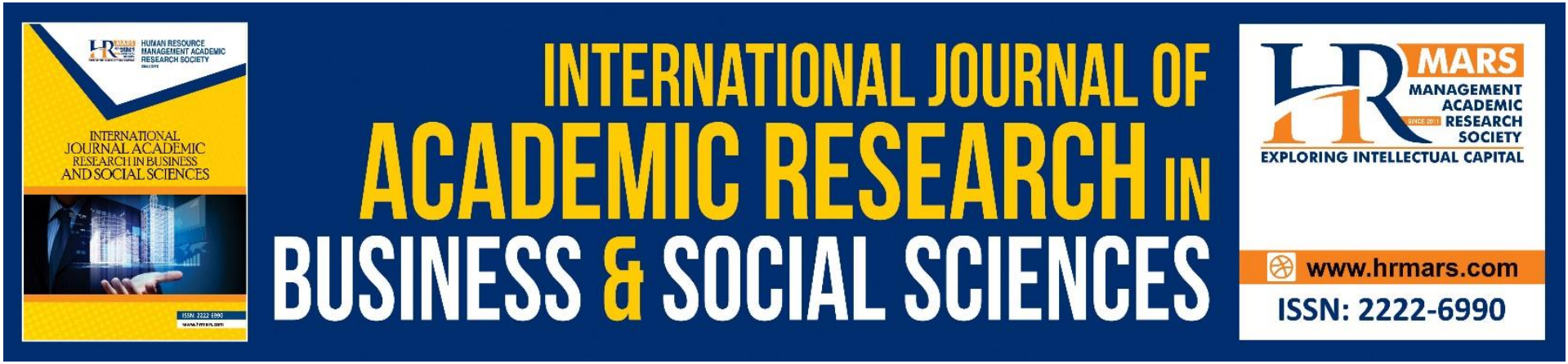

\title{
Social Entrepreneurship Intention: The Research Need
}

Siti Daleela Mohd Wahid, Siti Hajjar Mohd Amin, Siti Baizura Mohd Wahid.

To Link this Article: http://dx.doi.org/10.6007/IJARBSS/v11-i11/11046 DOI:10.6007/IJARBSS/v11-i11/11046

Received: 01 September 2021, Revised: 23 September 2021, Accepted: 19 October 2021

Published Online: 07 November 2021

In-Text Citation: (Wahid et al., 2021)

To Cite this Article: Wahid, S. D. M., Amin, S. H. M., \& Wahid, S. B. M. (2021). Social Entrepreneurship Intention: The Research Need. International Journal of Academic Research in Business and Social Sciences, 11(11), $317-330$.

\section{Copyright: (c) 2021 The Author(s)}

Published by Human Resource Management Academic Research Society (www.hrmars.com)

This article is published under the Creative Commons Attribution (CC BY 4.0) license. Anyone may reproduce, distribute, translate and create derivative works of this article (for both commercial and non-commercial purposes), subject to full attribution to the original publication and authors. The full terms of this license may be seen

at: http://creativecommons.org/licences/by/4.0/legalcode

Vol. 11, No. 11, 2021, Pg. $317-330$

http://hrmars.com/index.php/pages/detail/IJARBSS

JOURNAL HOMEPAGE

Full Terms \& Conditions of access and use can be found at http://hrmars.com/index.php/pages/detail/publication-ethics 


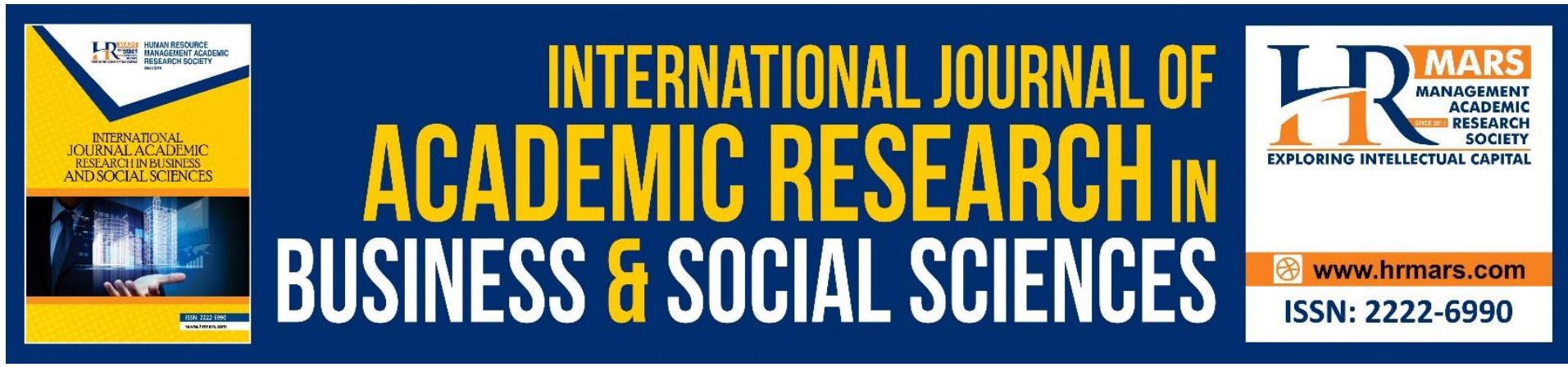

\title{
Social Entrepreneurship Intention: The Research Need
}

\author{
Siti Daleela Mohd Wahid \\ Faculty of Business and Management, Universiti Teknologi ARA, 78000, Alor Gajah, \\ Melaka, Malaysia \\ Email: sitid365@uitm.edu.my \\ Siti Hajjar Mohd Amin \\ Faculty of Administrative Science and Policy Studies, Universiti Teknologi MARA, \\ 40450 Shah Alam, Selangor, Malaysia \\ Email: hajjar@uitm.edu.my
}

\section{Siti Baizura Mohd Wahid \\ Minaz Sdn. Bhd.}

No. 13A, Jalan Kiara 2, Kawasan Perniagaan Kiara, 43500, Semenyih, Selangor, Malaysia Email: baizura.minaz@gmail.com

\begin{abstract}
Social entrepreneurship (SE) is an innovative entrepreneurial approach that uses business skills to undertake entrepreneurial activities that address socio-economic problems and pursue social values. Among the important roles of SE with regards to society are its ability to reduce poverty, provide basic education, champion gender equality, reduce infant and child mortality, and protect the environment. Despite of its success, the involvement of individuals in SE activities especially in Malaysia is at unsatisfactory level. Past scholars mentioned, "if we are interested in studying new ventures, then we must understand the processes that lead up to their initiation." With this suggestion, it is essential to know why some individuals create a social enterprise while others do not. To begin, we reveal the cognitive approach for individual to become social entrepreneur. We overview the SE development in Malaysia and summarize numerous relevant theories for intention-based studies. Interestingly, we also identify the most used predictors in SE intention realm. At the end of this article, we proposed potential practical contributions for interested parties who wish to pursue this area.
\end{abstract}

Keywords: Social Entrepreneurship, Cognitive, Intention, Malaysia

\section{Introduction}

Social entrepreneurship (SE) is an innovative entrepreneurial approach that uses business skills to undertake entrepreneurial activities that address socio-economic problems and pursue social values. Currently, this innovative approach is of a great interest and concern to 
local and international parties (i.e., policies makers, academics, practitioners) due to its significant effects on the social and economic transformation of a country (Barton et al., 2018; Chinchilla \& Garcia, 2017; Hockerts, 2017; Medyanik \& Al-Jawni, 2017). Among the important roles of SE with regards to society are its ability to reduce poverty, provide basic education, champion gender equality, reduce infant and child mortality, combat HIV, malaria and protect the environment (Borstein \& Davis, 2010; Wahid et al., 2016).

Although the presence of traditional entrepreneurs can raise the standard of living in a community, social entrepreneurs are perceived to be more capable of solving large-scale social problems (Barton et al., 2018; Nasir \& Subari, 2017; Rahman et al., 2016). Several organizations have effectively improved the lives of thousands of people around the world. As an example, a well-known and established organization, Ashoka, in the United States of America, founded by Bill Drayton, has captured the value of social endeavors (Bornstein \& Davis, 2010). Ashoka is the first institution with the aim of finding potential social entrepreneurs and providing them a wide range of assistance (i.e., business consulting, business coaching) to pursue their goals. Another example is the Schwab Foundation in Switzerland, which seeks to advance SE for societal innovation. In the United Kingdom, SE has been present since 2000 (Defourney \& Nyssens, 2008; Ernst, 2011). Moreover, Bornstein and Davis (2010) even believe that the preoccupation with SE in the United States of America and Europe has already reached its third generation of development.

Malaysia is also an active participant in promoting SE and there are many successful social entrepreneurs established in the country, including Yasmin Rashid (founder of EcoKnight), Sasibai Kimis (founder of Earth Heir) and Abbie Hossanna (founder of The Backyard Tour Guide). SE conduct in Malaysia has been noticeable since the formation of the Cooperation and Ikhtiar Project in 1986. For example, the Amanah Ikhtiar Malaysia (AIM) and Tabung Ekonomi Kumpulan Usaha Niaga (TEKUN) are many of the entities that have started early efforts to promote social development and improve the status quo in Malaysia (Kadir \& Sarif, 2016). Currently, there are a growing number of supportive intermediaries such as myHarapan, iM4U, Impact Hub, Tandemic, Social Enterprise Alliance and Enactus Foundation. Together with local universities, they actively participate in generating awareness about social enterprises and helping the community with numerous SE programs. Even though these intermediaries have actively created awareness and supported the community, their initiatives alone are insufficient to fully understand the potential of this sector.

Technically, the practice of SE has existed for decades, but just recently it became an active focus of academic research and many leading journals that are publishing on this growing topic. For instance, the Journal of Entrepreneurship Theory \& Practice (Q1) published a special issue on SE in July 2010. Other journals, like Journal of Social Entrepreneurship (Q3), International Journal of Social Entrepreneurship and Innovation (Q3), and Social Enterprise Journal (Q4) focus entirely about SE. Similarly, this growth of interest is also visible by doing a Google search for 'social entrepreneurship'. In 2005, this search produced 158,000 hits. In 2011, the same search generated over 2.5 million hits (Ernst, 2011). In 2015, it was over 3.5 million, in 2016, it was over 4.8 million (Tran, 2018) and in 2018, it was over 8.8 million hits.

It is evident from the burgeoning literature of SE that it has a great potential to transform the future of an individual, organization, community, or a country (Ahuja et al., 2019; Mohamad, 2012). The qualities and characteristics possessed by social entrepreneurs should be nurtured in students at higher learning institutions (HLIs). Early emphasis at the university level is believed to be favorable to arousing their minds and attitudes to be more creative. This exposure can benefit students whereby, they can think critically on how to assist 
the less-privileged community to transform their lives to be better (Ayob, 2017; Abdullah et al., 2012; Wahid et al., 2018). On the other hand, the aspiration of students to become social entrepreneurs can inspire their career choice once they have graduated (Rahman et al., 2016). Furthermore, the government also welcomes the SE approach to help strengthen the country's innovation systems by actively looking for the best methods to enhance the socioeconomic status of its citizens. Therefore, the positive effects of SE on transforming a nation have made this topic a fruitful area of inquiry in the field of entrepreneurship research.

Despite its potential to transform the lives of those less fortunate, and its influence on policies and procedures, the theoretical investigation of this phenomenon is in its beginning (Ernst, 2011; Tran, 2018). SE remains largely a phenomenon driven (Tiwari et al., 2018). Consequently, the first step is a thorough examination on the scientific work in the discipline of SE. The subject of SE has a substantial appeal on many fronts. However, Aure (2018) recommended that impending research should focus on exploring the connection between cognition and SE. This direction leads to better understanding on how and why entrepreneurs think and act. As a prominent scholar, Krueger (2000) explains, "if we are interested in studying new ventures, then we must understand the processes that lead up to their initiation." Following this recommendation, it is important to know why some individuals create a social enterprise while others do not.

\section{The Cognitive Approach to Describe Intention}

In this article, cognitive approach refers to the 'intention' concept which has been proven to be the finest predictor of planned behaviors (Ajzen, 1991). "Intention refers to the willingness or readiness to engage in behavior under consideration" (Han \& Kim, 2010). It is widely accepted that all planned behaviors are intentional (Krueger, 2000). In this context, any decision to begin a new social enterprise is planned rather than being a conditioned response (Barton et al., 2018; Krueger et al., 2000). Subsequently, intention as the first phase of behavior should be investigated (Tran, 2018); if an individual possesses an entrepreneurial intention, he or she is more likely to perform the entrepreneurial behavior (Ajzen, 1991). Consequently, examining entrepreneurial intention plays a pivotal role in comprehending why someone chooses to be an entrepreneur. The following studies serve as the scientific basis for this topic:

Mair and Noboa (2006), in the first effort to develop the social entrepreneurship intention (SEI) model, contend that the unique components of the SE context require an adaptation of the traditional measures used in the theory of planned behavior (TPB) and entrepreneurial event model (EEM). They propose four factors of SEl: empathy, moral judgment, self-efficacy, and perceived social support (PSS). Their model has been deliberated theoretically by Tukamushaba et al. (2011) who applied it to an international context. Only a few scholars have attempted to empirically verify the model with modifications. For example, Hockerts $(2017 ; 2015)$ has modified the model by using the four factors as the mediators and added the construct of 'prior experience' as the predictor. Following similar approach, Medyanik and Al-Jawni (2017) have empirically confirmed the studied factors were significantly related to SEI in the context of Syria.

Ernst (2011) carried out a doctoral thesis in University of Wuppertal, Berlin to assess SEI on a sample of 203 students. She studied the effects of the factors namely SE personality traits, SE human capital and SE social capital to predict the SEI. Ernst (2011) is among the earliest scholars studying SEI formation in detail. She found partial support for her tested hypotheses' development. Some of her findings are at odds with the propositions advanced 
by Mair and Noboa (2006). Increased empathy, for instance, is found to decrease the attitude respondents have towards becoming social entrepreneurs.

Hockerts (2015) tried to corroborate the model of Mair and Noboa (2006). He made some modifications to the model by eliminating the mediating variables (i.e., perceived desirability and perceived feasibility) and verified the direct effect of moral obligation, selfefficacy, empathy, and PSS on SEI. Two years later, Hockerts (2017) further added the variable of 'prior experience' to the model and the effect of 'prior experience' was mediated by the four factors namely moral obligation, self-efficacy, empathy, and PSS. Surprisingly, the two studies which were conducted in 2015 and 2017 produced inconsistent findings; one study showed a positive relationship between empathy and SEI, and the other study showed an insignificant relationship.

Politis et al (2016) investigated the formation of SEI among 111 postgraduate students in the Southeast European region. In their study, the variables included personality traits, demographic characteristics, attitudinal constructs of TPB and situational factors. The study found that personality traits failed to predict SEI. The attitudes toward SE (ATSE) and perceived behavioral control (PBC) did show a substantial impact on SEI, but subjective norms $(\mathrm{SN})$ did not.

Tiwari et al. $(2018,2017 a, 2017 b, 2017 c)$ intended to determine the precursors of SEI among undergraduate students in India. The study anticipates the effects of emotional intelligence, moral obligation, creativity (Tiwari et al., 2017b), cognitive style (Tiwari et al., 2017a) and emotional intelligence, self-efficacy (Tiwari et al., 2017c). There are mixed results among the variables tested. Some of the papers report that PBC has the strongest effect on SEI. Some attempted to claim that SN experience the weakest relationship with SEI. Another odd finding is the varying results regarding emotional intelligence (Tiwari et al., 2018, 2017b, 2017c). Moreover, mixed findings required further investigation. All studies form the basis of current SE literature that seeks to understand what influences the development of social ventures. Their techniques use a quantitative approach to capture the venture creation phase. Accordingly, we should use the similar processes to discover what factors influence SEI amongst Malaysian.

\section{Social Entrepreneurship as a Potential Sector in Malaysian Economic}

As Malaysia moves towards the position of a high-income country, an inclusivity agenda has been the central tenet of Malaysia's government and it has made it a top priority to address the needs of its marginalized groups. Even though, Malaysia's different ethnic groups peacefully coexist, the government needs to address its socio-economic challenges to become an advanced economy (Khazanah Research Institute, 2018; Ayob et al., 2013). Numerous economic indicators have been identified, including poverty and unemployment (Khazanah Research Institute, 2016).

It is possible that the poverty rate can decline while the number of impoverished people increases (Khazanah Research Institute, 2018). In a hypothetical example, in one-year Malaysia has a poverty rate of 40 percent, while in the following year its poverty rate is 30 percent. The percentage of households living in poverty has clearly fallen. However, the population count can change. In this example, the population the first year was 10.0 million while the population in the following year was 20.0 million. This would mean that there were 4.0 million poor households in the first year and 6.0 million in the following: the number of poor households increased by 2.0 million. As reported by the Malaysia Department of Statistics, in 2016, approximately 6 percent of Malaysian households earned less than 
RM1,000 per month. Roughly 1.9 million Malaysian households are deprived of even necessities including healthcare and basic education (Khazanah Research Institute, 2016).

The unemployment rate in Malaysia was 3.4 percent in 2017 (Malaysia Department of Statistics). Surprisingly, youth unemployment in 2017 was 10.8 percent, three times higher than the national average. The rising youth unemployment rate was due to the increasing numbers of unemployed university graduates, about 204,000 individuals, who constituted 40.5 percent of those unemployed (Malaysia Department of Statistics; Malaysia Industrial Development Finance Research). This situation would benefit from an innovative solution directed at managing social problems (Abdul Kadir \& Sarif, 2016). Entrepreneurship is good for society, leading to innovation, fostering employment, and sustaining economic growth (Ip et al., 2017). By treating SE as a form of entrepreneurial activity, it may be considered valuable to society because SE aims social needs unmet by the government or private sectors.

Social entrepreneurs can demonstrate helpful in alleviating these issues by placing those less fortunate towards a better life (Sarif et al., 2013; Tran, 2017). However, the prevalence rate of SE activities in Malaysia is less than $2 \%$ of the entire population which is far behind comparable developing countries such as Thailand, Indonesia, and Argentina (Rahman et al., 2016). Bosma et al., (2016) in Global Entrepreneurship Monitor (2015) (Special Topic Report on Social Entrepreneurship) claim that Malaysian citizens in the 18-64 age bracket who are active as social entrepreneurs is one of the lowest levels when compared to other efficiency-driven economies (see Figure 1). The fact that SE levels are low is a 'problem' for Malaysian society, as the country may be missing out on an innovative way to support its citizens (Nasir \& Subari, 2017; Hussain et al., 2014).

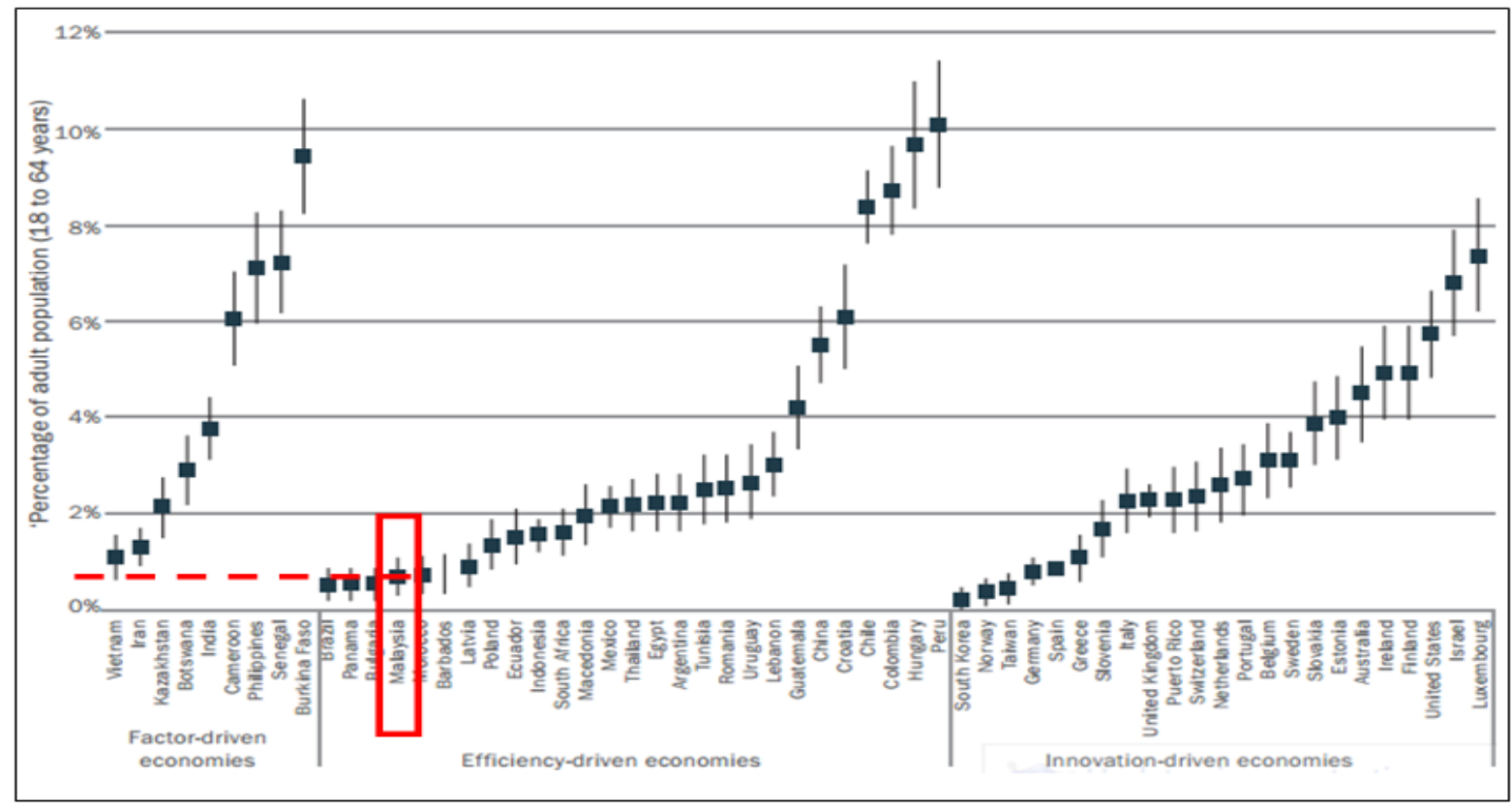

Figure 1 Prevalence of Social Entrepreneurship Across Countries Sources: Bosma et al (2016); Global Entrepreneurship Monitor (2015)

Today, the language of innovation is more vocal and earnest. According to Hussain et al. (2014) citizens can be the source of innovative ideas. Citizen-driven innovations will introduce divergent thinking which helps find novel solutions to complex problems. To be a developed nation, innovation will be one indicator to ensure the country achieves its aims. As reported by Dutta et al (2017) in the Global Innovation Index Report (2017), Malaysia 
ranked 37 out of 127 countries worldwide. As this ranking shows, we are aggressively pursuing our place as a developed economy. Although we are at a steady position, we still need the social entrepreneurship to be the 'change maker' to accomplish our agenda of becoming a developed economy.

Although, SE is effective, participation is very low. One demanding question emerges: how can the level of SE involvement in Malaysia be increased? The dominant views of Bosch (2013); Ernst (2011);Tiwari et al (2018) suggest that the quantity and quality of entrepreneurship can be boosted via empowerment among potential social entrepreneurs. Therefore, it is timely to scrutinize the factors influencing SEI in Malaysia. Wahid (2020) identified seven (7) commonly used predictors that influence direct and indirect relationship on SEI by using systematic literature review technique (see Table 1). She also summarized relevant theories and model available to explain 'intention' (see Table 2).

\section{Intention-based Theories}

To begin, we have separated the theories and model into two: classical theories of behavioural intention (1970s - early 1990s) and contemporary theories of behavioral intention (Mid 1990s - 2000). Under classical theories of behavioral intention, we identified six relevant behavioral theories namely Theory of Reasoned Action (TRA), Norm-Activation Model (NAM), Theory of Self-Regulation (TSR) and Theory of Planned Behavior (TPB), Entrepreneurial Event Model (EEM) and Bird's Model.

Starting mid-1990s, a blast of research was published on entrepreneurship intention models as a framework, thereby approving the applicability of the concept in various settings. Six theories and models have been found that specifically addressed entrepreneurship intention: Theory of Planned Behavior Entrepreneurial Model (TPBEM), Social Cognitive Career Theory (SCCT), Entrepreneurial Potential Model (EPM), Revised Entrepreneurial Intention Model (REIM), Extended Theory of Planned Behavior (ETPB) and Davidsson's model. During the early 2000s, there were no new models or theories related to intention studies; most were integrated entrepreneurial models. In 2006, Mair and Noboa where the first authors introduce Social Entrepreneurship Intention (SEI) Model. 
Table 1 List of commonly used predictors for SEI study

\begin{tabular}{|c|c|c|c|c|c|c|c|c|}
\hline Author(s) & Year & ATSE & SN & PBC & $\mathrm{MO} / \mathrm{MJ}$ & EMP & SE & PSS \\
\hline Adelekan et al. & 2018 & $x$ & $X$ & $x$ & & & & \\
\hline Aure & 2018 & & & & $x$ & $x$ & $x$ & $x$ \\
\hline Barton et al. & 2018 & & & & & & & \\
\hline Hockerts & 2018 & & & & $x$ & $x$ & $x$ & $x$ \\
\hline Ip et al. & 2018 & & & & $x$ & $x$ & $x$ & $x$ \\
\hline Kruse et al. & 2018 & $x$ & $x$ & $x$ & & & & \\
\hline Lacap et al. & 2018 & & & & $x$ & $x$ & $x$ & $X$ \\
\hline Luc & 2018 & $x$ & $\mathrm{x}$ & $x$ & & & & \\
\hline Rashid et al. & 2018 & & & & & $x$ & $x$ & \\
\hline Polbitsyn and Abidullah & 2018 & $\mathrm{x}$ & $x$ & $x$ & & & & \\
\hline Wahid et al. & $2018 a$ & $x$ & $x$ & $x$ & $x$ & $x$ & $x$ & $X$ \\
\hline Wahid et al. & $2018 b$ & $x$ & $x$ & $x$ & & & & \\
\hline Tiwari et al. & 2018 & $\mathrm{x}$ & $x$ & $x$ & $\mathrm{x}$ & & $x$ & \\
\hline Chengalvala and Rentala & 2017 & $x$ & & $x$ & & & & \\
\hline Hockerts & 2017 & & & & $x$ & $x$ & $x$ & $x$ \\
\hline Ip et al. & 2017 & & & & $\mathrm{x}$ & $x$ & $x$ & $x$ \\
\hline Medyanik and Al-Jawni & 2017 & & & & $x$ & $x$ & $x$ & $x$ \\
\hline Tiwari et al. & $2017 a$ & $x$ & $x$ & $x$ & & & $x$ & \\
\hline Tiwari et al. & $2017 b$ & $x$ & $x$ & $x$ & $x$ & & & \\
\hline Tiwari et al. & $2017 c$ & $x$ & $x$ & & & & $x$ & \\
\hline Chipeta et al. & 2016 & $x$ & & $x$ & & & & \\
\hline Politis et al. & 2016 & $x$ & $x$ & $x$ & & & & \\
\hline Wilton & 2016 & & & & & $x$ & $x$ & \\
\hline Chipeta & 2015 & $x$ & & $x$ & & & & \\
\hline Hockerts & 2015 & & & & $x$ & $x$ & $x$ & $x$ \\
\hline Urban and Teise & 2015 & & & & $\mathrm{X}$ & & $x$ & $x$ \\
\hline Yang et al. & 2015 & $\mathrm{x}$ & $x$ & $x$ & & & & \\
\hline D’Orazio et al. & 2013 & & & & & & & \\
\hline Noorseha et al. & 2013 & & & & & $x$ & & \\
\hline Ernst & 2011 & $x$ & $\mathrm{x}$ & $x$ & & & & $x$ \\
\hline Total & & 16 & 13 & 15 & 12 & 12 & 15 & 11 \\
\hline
\end{tabular}

Note:

1. ATSE=Attitude towards social entrepreneurship

2. $\mathrm{SN}=$ Subjective norm

3. $\mathrm{PBC}=$ Perceived behavioral control

4. $\mathrm{MO} / \mathrm{MJ}=$ Moral obligation/Moral judgment

5. $E M P=E m p a t h y$

6. $S E=S e l f-e f f i c a c y$

7. PSS= Perceived social support 
Table 2 Relevant Theories and Model on Intention Studies

\begin{tabular}{|c|c|c|}
\hline Theories/Models & Advantages & Disadvantages \\
\hline $\begin{array}{l}\text { Theory of } \\
\text { Reasoned Action } \\
\text { (TRA) }\end{array}$ & $\begin{array}{l}\text { The TRA suggests that stronger } \\
\text { intentions lead to increase } \\
\text { effort to perform the behavior, } \\
\text { which also enhances the } \\
\text { likelihood for the behavior to } \\
\text { be performed. }\end{array}$ & $\begin{array}{l}\text { Unable to explicate individual's } \\
\text { non-volitional behavior. }\end{array}$ \\
\hline $\begin{array}{l}\text { Norm-Activation } \\
\text { Model (NAM) }\end{array}$ & $\begin{array}{l}\text { NAM suggest an individual } \\
\text { should takes full responsibility } \\
\text { to their actions taken. }\end{array}$ & $\begin{array}{l}\text { Fail to expound the role of } \mathrm{SN} \\
\text { and } \mathrm{PBC} \text {. }\end{array}$ \\
\hline $\begin{array}{l}\text { Theory of Self- } \\
\text { Regulation (TSR) }\end{array}$ & $\begin{array}{l}\text { TSR aims to seek } \\
\text { understanding on the } \\
\text { interrelationship } \\
\text { individual's among } \\
\text { affective, and } \begin{array}{r}\text { cognitive, } \\
\text { conative } \\
\text { variables simultaneously. }\end{array}\end{array}$ & $\begin{array}{l}\text { Fail to acknowledge the role of } \\
\text { external factors. }\end{array}$ \\
\hline $\begin{array}{l}\text { Theory of } \\
\text { Planned Behavior } \\
\text { (TPB) }\end{array}$ & $\begin{array}{l}\text { TPB is a strong theory that has } \\
\text { been widely used in the } \\
\text { entrepreneurship intention } \\
\text { domain and views intentions as } \\
\text { significant predictors of } \\
\text { behavior, mainly in the case of } \\
\text { planned and goal-oriented } \\
\text { behavior. }\end{array}$ & $\begin{array}{l}\text { It is generic model of intention. } \\
\text { Some argued that it is not suit } \\
\text { perfectly for all fields }\end{array}$ \\
\hline $\begin{array}{l}\text { Entrepreneurial } \\
\text { Event Model } \\
\text { (EEM) }\end{array}$ & $\begin{array}{l}\text { EEM is among the earliest } \\
\text { model introduced in the field } \\
\text { of entrepreneurship. }\end{array}$ & $\begin{array}{l}\text { Two pre-requisites should be } \\
\text { met first prior beginning a new } \\
\text { venture. }\end{array}$ \\
\hline Bird's Model & $\begin{array}{l}\text { Bird's Model is about } \\
\text { individual's state of mind } \\
\text { directing individual action } \\
\text { towards self-employment as } \\
\text { opposed to organization } \\
\text { employment. }\end{array}$ & $\begin{array}{l}\text { Only based on the rational and } \\
\text { intuitive thinking which } \\
\text { obviously hard to measure. The } \\
\text { previous work has yet to } \\
\text { validate Bird's model } \\
\text { empirically. }\end{array}$ \\
\hline $\begin{array}{l}\text { Theory of } \\
\text { Planned Behavior } \\
\text { Entrepreneurial } \\
\text { Model (TPBEM) }\end{array}$ & $\begin{array}{l}\text { TPBEM is the first model } \\
\text { introduced by Krueger and } \\
\text { Carsrud (1993) and lays fully in } \\
\text { the field of entrepreneurship. }\end{array}$ & $\begin{array}{l}\text { All constructs in the model is } \\
\text { the proxy of TPB. } \\
\text { Unfortunately, the model } \\
\text { needs to be revised especially } \\
\text { in the conceptual and } \\
\text { measurement issue }\end{array}$ \\
\hline $\begin{array}{lr}\text { Social } & \text { Cognitive } \\
\text { Career } & \text { Theory } \\
\text { (SCCT) } & \end{array}$ & $\begin{array}{l}\text { SCCT suggests that in making } \\
\text { decision related to career } \\
\text { issues, self-efficacy and } \\
\text { outcome expectation should } \\
\text { significantly related. }\end{array}$ & $\begin{array}{l}\text { This model is related to } \\
\text { decision-making process to opt } \\
\text { entrepreneurship as career } \\
\text { choice. Yet, limited study used } \\
\text { this theory to explain SEI. }\end{array}$ \\
\hline
\end{tabular}




\begin{tabular}{|c|c|c|}
\hline $\begin{array}{l}\text { Entrepreneurial } \\
\text { Potential Model } \\
\text { (EPM) }\end{array}$ & $\begin{array}{l}\text { EPM is aspires to be a } \\
\text { multilevel model, including } \\
\text { individual and organizational } \\
\text { constructs. }\end{array}$ & $\begin{array}{l}\text { The model investigates the } \\
\text { potential entrepreneur in two } \\
\text { disparate settings: corporate } \\
\text { ventured and enterprise } \\
\text { development in which not } \\
\text { suitable for the current } \\
\text { research setting }\end{array}$ \\
\hline $\begin{array}{l}\text { Revised } \\
\text { Entrepreneurial } \\
\text { Intention Model } \\
\text { (REIM) }\end{array}$ & $\begin{array}{l}\text { RIEM was introduced to } \\
\text { improve Bird's Model in which } \\
\text { self-efficacy plays a significant } \\
\text { role in the development of } \\
\text { entrepreneurial intentions and } \\
\text { actions. }\end{array}$ & $\begin{array}{l}\text { Only based on the rational and } \\
\text { intuitive thinking which } \\
\text { obviously hard to measure. }\end{array}$ \\
\hline $\begin{array}{l}\text { Extended or } \\
\text { Integrated Model }\end{array}$ & $\begin{array}{l}\text { Better model can be developed } \\
\text { and introduced. }\end{array}$ & $\begin{array}{l}\text { Most of them are developed } \\
\text { based on the original theory of } \\
\text { TPB. }\end{array}$ \\
\hline $\begin{array}{l}\text { Davidsson's } \\
\text { model }\end{array}$ & $\begin{array}{l}\text { Davidsson's Model was the } \\
\text { first model to investigate the } \\
\text { economic-psychological } \\
\text { factors that affect a person's } \\
\text { intention to become an } \\
\text { entrepreneur. }\end{array}$ & $\begin{array}{l}\text { Omit the external factor in the } \\
\text { model. }\end{array}$ \\
\hline
\end{tabular}

\section{Practical Implications for Social Entrepreneurship Intention Study}

Those who interested in studying SEl, it will indirectly contribute to our National Entrepreneurship Policy 2030 that was recently launched. As Malaysia's goal is to become an entrepreneurial country by 2030 necessitates the development of human and social capital, we can categorize any study's findings are considered as the initial start for forming SEI model. According to the Minister of Malaysia's Entrepreneur Development \& Cooperatives, there is a need for students to involve in societal-based activities. Moreover, "... society needs to be developed holistically; the universities and industries need to be given more incentives to spur the entrepreneurial development..." To achieve this national agenda, this article provides useful directions and practical implications for Malaysia's Higher Learning Institutions (HLIs), students, as well as policymakers.

\section{a. Practical Contribution to the Malaysia HLIs}

Firstly, we proposed that SE-educational program should be re-formed and re-designed accordingly which includes the policy, curriculum, and syllabus to capture student's interest in understanding SE. A study by Lewis (2002) showed that 70 percent of students are interested in starting their own business upon graduation, but 85 percent of them reported not being taught about how business is conducted and have little knowledge of how businesses operate. This underscores the necessity of learning the basic of SE. Therefore, this present study contributes to the practically of comprehending SE.

Secondly, a fruitful SE training should be executed to the students. Some of training programs that can be proposed include conducting real SE case studies, leading SE simulations, creating business incubators and providing relevant resources to enable students' ideas to be realized. Past literatures pointed out that if the students lack training, 
they are reluctant to accept the fact of comprehending SE. With this regard, continuous effort must be made to ensure that all students endure for SE training to improve the knowledge, skills, and ability to become social entrepreneurs.

Thirdly, together with knowledge and skills, attitudinal elements also influence venture creation because "what do I know, including what do I know how to do" (Tran, 2018). In addition, to enhance the entrepreneurship education, Malaysia HLIs should offer space outside of the university for students to take entrepreneurial initiatives. For instance, universities should organize a diversity of SE activities such as games, competitions, clubs, workshop, or conferences. Through such activities, SE spirit can be spread. It is a means of infusing competitive fire into a coherently safe environment and a means of finding good ideas or potential social entrepreneurs for nurturing.

At this point, Malaysia HLIs should organize talks, forums, social networking more frequent with social entrepreneurs for students, and/or should invite such social entrepreneurs to lecture during class programs. This approach will provide chances for students to get to know successful social entrepreneurs. Students can learn exposure, experience and specific traits or characteristics from these social entrepreneurs who can act as the role models and can even develop the motivation and enthusiasm to engage in SE. Malaysia's HLIs play a significant role in nurturing SE and stimulating the growth of social enterprises in Malaysia. In short, it allows students to build social enterprise ideas from the classroom, and then turn them into reality when they leave the university.

\section{b. Practical Contribution to the Students}

In line with developing human and social capital, the essentials related to student's attitudinal elements and support need to be enhanced as preparation for entering self-employment. Early exposure to SE-based programs is a good starting point for building a student's professionalism. In fact, student's involvements enable them to directly understand the social problems that are likely to elicit an increase in SEI. It is hoped that students will be able to recognize and understand that their involvement in SE-based programs at the university level is an impetus towards achieving academic success.

Student should portray a positive attitude towards SE to enhance the probabilities of the surrounding offering help. Besides, listening to a positive reinforcement from one's surroundings is needed for the prospectus social entrepreneurs like students. What the SEbased programs could do, nonetheless, is to raise awareness that aid students to show positive examples. This can include fostering a SE culture within the educational institutions itself (Ernst, 2011). Besides, to develop students' professionalism, existing entrepreneurialoriented programs and SE need to be refined with specific objectives to enhance the SE spirit among students. Effective SE courses need to be designed, formulated, and implemented. If any weaknesses in the curriculum are still not resolved, it will be impossible for SE-driven programs to generate more human capital for the country.

\section{c. Practical Contribution to the Policymakers}

This article also significantly contributes to assisting the policymakers to design a policy before the students plan to start-up their social enterprise. The effort made by our government in promoting SE is undeniable. The Ministry of Entrepreneur Development \& Cooperatives has launched the Social Enterprise Accreditation in April 2019, which is the biggest achievement in this field. This new national certification provides social enterprises with recognition and a means to communicate their commitments on social and environmental impact. Social 
Enterprise Accreditation offers a step-by-step playbook to facilitate social entrepreneurs through their accreditation process. The interested social enterprises must register themselves as a SE Basic where they declare themselves as a social enterprise who meets all requirements to become a social enterprise.

\section{Acknowledgement}

The thank you note address to the authors for the hard work. We also would like to express gratitude to the anonymous reviewers.

\section{References}

Abdullah, J., Rahim, M. H. L., \& Lajin, M. N. F. (2012). Social entrepreneurship at Universiti Teknologi MARA: The SIFE model. Proceedings of the ASEAN Entrepreneurship Conference 2012, pp. 365-370.

Kadir, M. A. B. A., \& Sarif, M. S. (2016). Social entrepreneurship, social entrepreneur, and social enterprise: a review of concepts, definitions, and development in Malaysia. Journal of Emerging Economies and Islamic Research 4(2): 1-16.

Wahid, H. A., Rhouse, M. S., Mustaffa, W. W.S ., Rahman, A. R. (2016). Social entrepreneurship and resilience among public university students in Malaysia. International Journal of Academic Research in Business and Social Sciences 6(12): 171-184.

Wahid, H. A., Rhouse, M. S., Samsudin, N., Rahman, A. R., Mustaffa, W. W. S., Razak, A. A. Z. B. (2017). Kompetensi komunikasi dalam kalangan pelajar Enactus dan bukan Enactus di universiti awam Malaysia. Journal of Humanities, Language, Culture and Business 1(1):121-132.

Ahuja, V., Akhtar, A., \& Wal, O. P. (2019). Development of a comprehensive model of social entrepreneurial intention formation using a quality tool. Journal of Global Entrepreneurship Research 9(41): 1-27.

Ajzen, I. (1991). The theory of planned behavior. Organizational Behavior and Human Decision Process 50(2): 179-211.

Aure, P. A. H. (2018). Exploring the social entrepreneurial intentions of senior high school and college students in a Philippine University: a PLS-SEM approach. Journal of Legal, Ethical and Regulatory Issues 21(2): 1-11.

Ayob, A. H. (2017). Diversity, trust, and social entrepreneurship. Journal of Social Entrepreneurship 9(1): 1-12.

Ayob, N., Yap, C. S., Sapuan, D. A., \& Rashid, M. Z. A. (2013). Social entrepreneurial intention among business undergraduates: an emerging economy perspective. Gadjah Mada International Journal of Business 15(3): 249-267.

Barton, M., Schaefer, R., \& Canavati, S. (2018). To be or not to be a social entrepreneur: motivational drivers amongst American business students. Entrepreneurial Business and Economics Review 6(1): 6-35.

Bornstein, D., \& Davis, S. (2010). Social Entrepreneurship: What Everyone Needs to Know. United State of America: Oxford University Press.

Bosch, A. D. (2013). A comparison of commercial and social entrepreneurial intent: the impact of personal values. Ph.D. Dissertation, Regent University, London.

Bosma, N., Schøtt, T., Terjesen, S., \& Kew, P. (2016). Global Entrepreneurship Monitors: Special topic report on social entrepreneurship. Wellesly, MA \& London: Babson College \& London Business School. 
Chinchilla, A., \& Garcia, M. (2017). Social entrepreneurship intention: mindfulness towards a duality of objectives. Humanist Management Journal 1(2):205-214.

Davidsson, P. (1995). Determinants of entrepreneurial intentions. Proceedings of the RENT IX Workshop, pp. 1-30.

Defourney, J., \& Nyssens, M. (2008). Social enterprise in Europe: Recent trends and developments. Social Enterprise Journal 4(3): 202-228.

Dutta, S., Lanvin, B., \& Wunsch-Vincent, S. (2017). The Global Innovation Index 2017: Innovation Feeding the World. 10th Edition. Geneva: Cornell University and World Intellectual Property Organization.

Ernst, K. (2011). Heart over mind-an empirical analysis of social entrepreneurial intention formation on the basis of the theory of planned behavior. Ph.D. Dissertation, University of Wuppertal, Germany.

Han, H., \& Kim, Y. (2010). An investigate of green hotel customers' decision formation: developing an extended model of the theory of planned behavior. International Journal of Hospitality Management 29(4): 659-668.

Hockerts, K. (2017). Determinants of social entrepreneurial intentions. Entrepreneurship Theory \& Practices 41(1):105-130.

Hockerts, K. (2015). The social entrepreneurial antecedents scale (SEAS): a validation study. Social Enterprise Journal 11(3): 260-280.

Ip, C. Y., Wu, S. C., Liu, H. C., \& Liang, C. (2017). Revisiting the antecedents of social entrepreneurial intentions in Hong Kong. International Journal of Educational Psychology 6(3): 301-323.

Khazanah Research Institute. (2018). Report on The State of Households 2018: Different Realities. Kuala Lumpur: Perpustakaan Negara Malaysia.

Khazanah Research Institute. (2016). Report on The State of Households II 2016. Kuala Lumpur: Perpustakaan Negara Malaysia.

Krueger, N. F. (2000). The cognitive infrastructure of opportunity emergence. Entrepreneurship Theory \& Practice 24(3): 9-27.

Krueger, N. F., \& Carsrud, A. (1993). Entrepreneurial intentions: applying the theory of planned behavior. Entrepreneurship \& Regional Development 5: 315-330.

Krueger, N. F., Reilly, M. D., \& Carsrud, A. L. (2000). Competing models of entrepreneurial intentions. Journal of Business Venturing 15(5/6): 411-432.

Lewis, A. (2002). Teaching entrepreneurship. Tech Directions 62: 5-6.

Mair, J., \& Noboa, E. (2006). Social entrepreneurship: How intentions to create a social enterprise get formed. In. Mair, J., Robinson, J. \& Hockerts, K. (eds.). Social Entrepreneurship, pp. 121-134. London: Palgrave Macmillan.

Medyanik, O., \& Al-Jawni, F. (2017). An investigation of students' social entrepreneurial intentions in Syria: An empirical test. In. Marx Gómez J., Aboujaoude M., Feghali K. \& Mahmoud T. (eds.). Modernizing Academic Teaching and Research in Business and Economics: International Conference MATRE 2016, Beirut, Lebanon, pp. 85-114. Cham: Springer.

Mohamad, A. (2012). Memperkasa usahawan sosial, tinta IPT. Berita Harian, 23 Februari: 15.

Nasir, N. R., \& Subari, M. D. (2017). A review of social innovation initiatives in Malaysia. Journal of Science, Technology, and Innovation Policy 3(1):9-17.

Politis, K., Ketikidis, P., Diamantidis, A. D., \& Lazuras, L. (2016). An investigation of social entrepreneurial intentions formation among South-East European postgraduate students. Journal of Small Business and Enterprise Development 23(4): 1120-1141. 
Rahman, R. S., Othman, N., Pihie, Z. A., \& Wahid, H. A. (2016). Entrepreneurial intention and social entrepreneurship among students in Malaysian higher education. International Journal of Economics and Management Engineering, 10(1), 175-181.

Rashid, N. S., Sarkam, S.,F., Yaacob, A. N. J., Mustapha, M., Jusoh@Hussain, N., \& Abdul Azis, R. (2018). Factors influencing student's social entrepreneurship intention: a case of Duta Jauhar program. International Academic Research Journal of Social Science 8(4): 1307-1321.

Sarif, M. S., Ismail, Y., \& Sarwar, A. (2013). Creating wealth through social entrepreneurship: a case study from Malaysia. Journal of Basic and Applied Scientific Research 3(3): 345353.

Tiwari, P., Bhat, A. K., \& Tikotia, J. (2017a). Predictors of social entrepreneurial intention: an empirical study. South Asian Journal of Business Studies 6(1): 53-79.

Tiwari, P., Bhat, A. K., \& Tikotia, J. (2017b). The role of emotional intelligence and self-efficacy on social entrepreneurial attitudes and social entrepreneurial intentions. Journal of Social Entrepreneurship 8(2): 165-185.

Tiwari, P., Bhat, A. K., \& Tikotia, J. (2017c). An empirical analysis of the factors affecting social entrepreneurial intentions. Journal of Global Entrepreneurship Research 7(9): 1-25.

Tiwari, P., Bhat, A. K., \& Tikotia, J. (2018). Factors affecting individual's intention to become a social entrepreneur. In. Agrawal, A. \& Kumar, P. (eds.). Social Entrepreneurship and Sustainable Business Models: The Case of India, pp. 59-98. Switzerland: Springer International Publishing.

Tran, A. T. P. (2018). Social entrepreneurial intention: an empirical study in Vietnam. Ph.D. Dissertation, Universitat Koblenz and Landau, Germany.

Tran, A. T. P. (2017). Factors influencing social entrepreneurial intention: A theoretical model. Proceedings of the 89th ISERD International Conference, pp. 51-57.

Tukamushaba, E. K., Orobia, L., \& George, B. P. (2011). Development of a conceptual model to understand international social entrepreneurship and its application in the Ugandan context. Journal of International Entrepreneurship 9: 282-298.

Wahid, S. D. M. (2020). Constructing Social Entrepreneurship Intentions Model in Malaysia: Multiple Mediators Analysis. Ph.D. Dissertation, Universiti Kebangsaaan Malaysia, Malaysia.

Wahid, S. D. M., Hussain, W. M. H. W., \& Ayob, A. H. (2018). The growing trend of social entrepreneurship among Malaysian undergraduate students. International Academic Research Journal of Social Science 8(9): 1034-1046.

Hussain, W. M. H. W., Ab Rahman, M. N., Zainol, Z. A., \& InayahYaakub, N. (2014). Mechanism and government initiatives promoting innovation and commercialization of university invention. VOL. 22 (S) JAN. 2014, 131. 